\title{
Hemşirelik öğrencilerinin meslek seçimini etkileyen faktörlerin belirlenmesi
}

\section{Determination of the factors that affect the choice of career of the nursing students}

\author{
Hüsna ÖZVERENª, Emel GÜLNAR', Dilek ÖZDEN²
}

'Kırıkkale Üniversitesi Sağlık Bilimleri Fakültesi, Kırıkkale,

${ }^{2}$ Dokuz Eylül Üniversitesi Hemşirelik Fakültesi, İzmir, TÜRKIYE

\section{öz}

Amaç: Bu araştırma hemşirelik öğrencilerin meslek seçimini etkileyen faktörlerin belirlenmesi amacıyla yapılmıştır.

Gereç ve Yöntemler: Tanımlayıcı tipteki araştırmanın örneklemini, 2012-2013 yılı güz yarıyılında Sağlık Bilimleri Fakültesi Hemşirelik Bölümünde öğrenim gören ve çalışmaya katılmayı kabul eden 175 öğrenci oluşturmuştur. Araştırmada veriler, öğrencilerin tanıtıcı özellikler formu ve Hemşire Meslek Seçimi Ölçeği (HMSÖ) kullanılarak toplanmıştır. Veriler yüzdelik hesaplaması, ortalama ölçüleri, Kruskal Wallis ve Mann-Whitney U testi kullanılarak değerlendirilmiştir.

Bulgular: Araştırma sonucunda, öğrencilerin \%89,7'sinin kız öğrenci ve \%53,1'inin düz liseden mezun olduğu saptanmıştır. Öğrenci hemşirelerin; cinsiyet, hemşirelik bölümü isteyerek gelme durumu, kendini mesleğe hazır hissetme durumu, hemşirelik mesleğini sevme durumu ve mezuniyet sonrası hemşirelik mesleğini yapmak isteme durumuna göre meslek seçimi ölçeği puanı ortalamaları arasındaki fark istatistiksel olarak anlamlı bulunmuştur.

Sonuçlar: Öğrencilerin meslek seçiminde cinsiyetin, bölümü isteyerek gelme durumunun, mesleğe hazır hissetme durumunun mezuniyet sonrası hemşirelik yapma ve hemşireliği sevme durumu gibi bazı değişkenlerin etkili olduğu bulunmuştur. Akademisyenlerin, öğrencilere hemşirelik mesleğinin tanıtımında rehberlik yapması önerilir.

Anahtar Kelimeler: Hemşirelik öğrencisi, meslek seçimi, hemşirelik

Corresponding Authora: Hüsna Özveren, Kırıkkale Üniversitesi Sağlık Bilimleri Fakültesi, Yenişehir, Yahşihan, Kırıkkale, TURKEY. 


\section{ABSTRACT}

Aim: This research has design to determine of factors affecting the choice of career of the nursing students

Material and Methods: The research is designed by descriptive methods. The research group is constituted 175 students who are educating at faculty of health science in 2012-2013 spring semesters. Research data are collected by student's information from and Nursing Career Decision Scale. Data were evaluated with using Kruskal Wallis, Mann Whitney U, Medium value and average measure.

Results: The percentage average of the student is $89.7 \%$ female, the percent average of the students who were graduated in high school 53.1\%. Nursing student's career decision scale are affected by their sexuality their desicion when they prefer the nursing department, their feeling to ready to this profession, their condition to love this profession and after graduating to prefer working this profession. This factors was statistically significant difference was found.

Conclusion: When students choose career decision, some factors are effective. This factors are sexuality their decision when they prefer the nursing department, their feeling to ready to this profession, their condition to love this profession and after graduating to prefer working this profession. Profession's suitable introduction and guidance by academician to student who want to choose this profession, is important.

Keywords: Nursing students, career choice, nursing

\section{Giriş}

Meslek kişinin kimliğinin en önemli kaynağı olup, onun etraftan saygı görmesine, başkaları ile ilişki kurmasına, toplumda iyi bir yer edinmesine ve işe yaradığı duygusunu yaşamasına olanak veren bir etkinlik alanıdır [1,2]. Meslek seçimiyse, bireyin çeşitli meslek gruplarından en iyi yapabileceğini düşündüğü faaliyetleri içeren ve kendisinin en üst düzeyde doyum sağlayacağına inandığı bir alana yönelmesidir [3]. Bireyin kendine ve topluma daha faydalı olabilmesi için uygun meslek seçmesi gerekir. Meslek seçimi kararı, insanın yaşamı boyunca vereceği en önemli kararlardan biri olup, meslek seçiminin bilinçli yapılması hem birey hem de ülke geleceği açısından büyük önem taşımaktadır. Çünkü birey verdiği kararla tüm yaşantısına şekil verecek bir süreci, yaşayacağı çevreyi ve ilişkide bulunacağı insanları da seçmiş olacaktır. Aynı zamanda meslek seçimi, kişinin aile gelirini, geçim tarzını, işini isteyerek yapıp yapmamasını, sorumluluk duygusunu ve mutlu olup olmamasını belirleyecek derecede önemlidir. Bu anlamda insanın yaşam biçiminin de seçimi olarak ifade edilebilecek meslek seçimi, insan hayatının en önemli dönüm noktalarından birisidir. Bu nedenle, bireyin mesleğine yönelik doğru bir karar alması, yaşamında mutlu ve başarılı olabilmesinde önemli rol oynamaktadır [4].

Meslek seçimi her bireyde olduğu gibi hemşirelik mesleği içinde oldukça önemlidir. Sağlık hizmetinin en önemli meslek gruplarından biri olan hemşirelik; bireyin, ailenin ve toplumun sağlık düzeyinin yükseltilmesinde, sağlık hizmetlerinin planlanması ve değerlendirilmesinde temel insan gücü olarak önemli bir yere sahiptir. Gelişen dünyamızın sağlık gereksinimleri artarken, hemşirelerin sağlık hizmetindeki rolü de artmaktadır [3,5]. Hemşirelik mesleği sağlığın korunması, geliştirilmesi ve hastalık durumunda iyileştirme gibi önemli sorumluluklar yüklenen bir meslektir. Bu sorumlulukların yerine getirilebilmesi, hemşirelik mesleğini yürütecek kişilerin mesleği isteyerek seçmesi, mesleğin toplumdaki saygınlığı için mesleğe sahip çıkması ve eğitimi süresince aldığı bilgi ve geliştirdiği becerilerini en iyi şekilde uygulama çabası içinde olması gerekir $[6,7]$. Meslek seçiminde her öğrencinin kendi yeteneği ve ilgisine göre tercihte bulunması beklenen bir durumdur. Ancak, kişisel özelliklerin yanı sıra çevresel ve ekonomik koşullar, rastlantılar gibi birçok faktör öğrencinin geleceği açısından etkili olabilmekte ve hemşirelik mesleği de diğerleri gibi rastlantısal olarak bilmeden ve istemeyerek seçilebilmektedir [3,8,9]. Yapılan çalışmalarda, üniversitede hemşirelik mesleğini seçen öğrencilerin iş bulma olanaklarının iyi olması, mesleğe duyulan ilgi, aile isteği, ailede hemşire olması, medya ve televizyondan etkilenme, puanın hemşireliğe yetmesi, açıkta kalmama, sınav puanı, mesleğin toplumsal saygınlığının dürüstlük ve sorumluluk getiren konumda olması ve kişinin meslekte özgür olması gibi faktörlerin, meslek seçimini etkilediği saptanmıştır [3,9-16]. 
Hemşirelik mesleğini yürütecek kişilerin mesleği isteyerek seçmesi, mesleğintoplumdakisaygınlığı, mesleğesahipçıkması ve eğitimi süresince aldığı bilgi ve geliştirdiği becerilerini en iyi şekilde uygulaması için gereklidir [17]. Hemşirelik mesleğinin çalışma koşullarını ve çalışma alanlarını tanıyıp isteyerek seçen bireylerin o mesleği gerektiği şekilde yürütmesi, hem bu meslekte çalışanların verdiği hizmetten doyum bulmasını, hem de hizmet alan bireylerin yarar görmesini ve memnun kalmasını sağlar [18]. İstemeden seçtikleri bölümde okuyan hemşirelik öğrencilerinin mesleklerinde başarılı ve verimli olma olasılığı düşüktür [19].

İnsan sağlığının korunmasında, iyileştirilmesinde ve geliştirilmesinde önemli bir yeri olan hemşirelik mesleğinin gençler tarafından bilinerek ve istenerek seçimi meslek bilincinin oluşumunda önemlidir [17]. Ülkemizde hemşirelik mesleğinin ilerlemesi, statüsünün yükseltilmesi için mesleğin tam anlamıyla uygulanıp yerine getirilmesi önemlidir. Bu nedenle mesleği seçen hemşirelik öğrencilerinin bilinçli olarak seçmeleri, iyi tanımaları, kabullenmeleri ve sevmeleri gerekmektedir. Bu nedenle hemşirelik öğrencilerinin de meslek seçimini etkileyen faktörlerin bilinmesi önemlidir. Böylece yanlış, eksik bilgilenmeler ve bu bilgilerin kaynağı belirlenerek, çalışan profesyonel kişilere yeterli tanıtım ve bilgilendirme ile hemşireliğin aranan ve tercih edilen bir meslek haline getirilmesine katkı sağlayacaktır [20]. Bu araştırma hemşirelik öğrencilerinin meslek seçimini etkileyen faktörlerin belirlenmesi amacıyla yapılmıştır.

\section{Gereç ve Yöntemler}

Bu araştırma tanımlayıcı olarak yapılmıştır. Araştırma 20122013 yılı güz yarıyılında bir üniversitenin Sağlık Bilimleri Fakültesi Hemşirelik Bölümünde yapılmıştır. Araştırmanın evrenini bir üniversitenin Sağlık Bilimleri Fakültesi Hemşirelik Bölümünde öğrenim gören öğrenciler oluşturmuştur. Araştırmanın örneklemini ise çalışmaya katılmayı kabul eden 175 öğrenci oluşturmuştur.

Araştırmada veriler, öğrencilerin tanıtıcı özellikler formu ve Hemşire Meslek Seçimi Ölçeği (HMSÖ) kullanılarak toplanmıştır. Tanıtıcı özellikler formu araştırmacı tarafından literatürden yararlanılarak [3,14,17,21-23] hazırlanan 26 sorudan oluşmaktadır. Formdaki sorular öğrencilerin yaş, cinsiyet, anne-baba eğitim düzeyi, tercih sırası gibi meslek seçimini etkileyen soruları içermektedir.
Hemşirelikte Meslek Seçimi Ölçeği (HMSÖ), hemşirelik öğrencilerinin meslek seçimini etkileyen nedenlerinin belirlenmesine yönelik olan bu ölçek Zysberg ve Berry [24] tarafından geliştirilmiştir. Ölçeğin Türkiye'de geçerlilik ve güvenilirlik çalışması, Önler ve Saraçoğlu (2010) tarafından yapılmıştır. Likert tipinde yanıtlanan ölçek (\%0 ile \%100 arası), 17 madde ve iki alt ölçekten (mesleki uygunluk, yaşamsal nedenler) oluşmaktadır. Ölçeğin mesleki uygunluk ve yaşamsal nedenler alt faktörleri için Cronbach Alfa değerleri 0,86 ve 0,78 'dir. Mesleki uygunluk faktörü on bir sorudan, yaşamsal nedenler faktörü altı sorudan oluşmaktadır. Her bir madde $\% 0$ (meslek seçimimde etkili olmadı) ve \%100 (meslek seçimimde en önemli etkendir) arasında derecelendirilmiştir. Toplam ölçek ve alt ölçek puanları; katılımcıların ölçeğe verdikleri puanların toplamının, ölçekteki soru sayısına bölünmesiyle elde edilmektedir.

Araştırma Helsinki illkeleri Deklerasyonuna uygun olarak hazırlanmış, uygulamaya başlanmadan önce araştırmanın yapılacağı kurumdan yazılı izin alınmıştır. Araştırmaya katılan öğrencilere önce araştırmanın amacı açıklanmış, katılımın gönüllülük esasına dayalı olduğu ve bu çalışmadan toplanılacak verilerin sadece araştırma kapsamında kullanılacağı konusunda açıklama yapıldıktan sonra sözel ve yazılı onamları alınmıştır. Verilerin değerlendirilmesinde yüzdelik hesaplaması, ortalama ölçüleri, Kruskal Wallis ve Mann-Whitney $U$ testi kullanılarak değerlendirilmiştir.

\section{Bulgular}

Araştırmaya katılan öğrencilerin tanıtıcı özelliklerine bakıldığında $\% 89,7$ 'sinin kız öğrenci ve $\% 53,1$ 'inin düz liseden mezun olduğu saptanmıştır. Öğrencilerin \%37,1'inin 1. sınıf, \%28,6'sının 2. sınıf, \%21,7'sinin 3. sınıf, \%12,6'sının 4. sınıfolduğu ve $\% 60,9$ 'unun ise bölümü isteyerek geldiği belirlenmiştir. Araştırma kapsamına alınan öğrencilerin \%87,5'inin annesinin, \%63,5'inin babasının ilkokul mezunu olduğu ve \%74,9'unun maddi durumlarını orta düzeyde belirttikleri saptanmıştır.

Öğrencilerin hemşirelik bölümünü tercih etme durumuna ilişkin özellikler incelendiğinde, \%14,3'ünün hemşirelik bölümünü ilk sırada tercih ettiği, \%46,9'unun meslek seçiminde ailesinin etkili olduğu, \%76,0'sının hemşirelik mesleğini sevdiğini, \%49,7'sinin hemşirelik mesleğine kendini hazır hissettiğini ve \%32,0'si mezun olduğunda hastanede hemşire olarak çalışmak istediğini belirtilmiştir (Tablo 1). 


\begin{tabular}{|c|c|c|}
\hline \multicolumn{3}{|c|}{$\begin{array}{l}\text { Tablo 1. Öğrencilerin hemşirelik bölümünü tercih etme } \\
\text { durumuna ilişkin özellikleri }(n=175)\end{array}$} \\
\hline Öğrencilerin Özellikleri & Sayı & $\%$ \\
\hline \multicolumn{3}{|l|}{ Tercih Sırası } \\
\hline 1. sırada & 25 & 14,3 \\
\hline 2. sırada & 14 & 8,0 \\
\hline 3. sırada & 31 & 17,7 \\
\hline 4. sırada & 17 & 9,7 \\
\hline 5. sırada & 23 & 13,1 \\
\hline Diğer & 65 & 37,1 \\
\hline \multicolumn{3}{|l|}{ Meslek Seçiminde Etkili Olan Kişi } \\
\hline Kendisi & 71 & 40,6 \\
\hline Ailesi & 82 & 46,9 \\
\hline Öğretmenleri & 16 & 9,1 \\
\hline Arkadaşları & 6 & 3,4 \\
\hline \multicolumn{3}{|l|}{ Hemşireliğe ilişkin duyguları } \\
\hline Hemşirelik mesleğini seviyorum & 133 & 76,0 \\
\hline Hemşirelik mesleğini sevmiyorum & 42 & 24,0 \\
\hline \multicolumn{3}{|l|}{ Mesleğe Hazır Hissetme Durumu } \\
\hline Evet & 87 & 49,7 \\
\hline Hayır & 88 & 50,3 \\
\hline \multicolumn{3}{|c|}{ Mezun Olunca Çalışmayı Düşündüğü Alan } \\
\hline Hastanede hemşire & 56 & 32,0 \\
\hline Hastanede yönetici hemşire & 48 & 27,4 \\
\hline Üniversitede akademisyen olmak & 46 & 26,3 \\
\hline Özel sağlık kuruluşu & 3 & 1,7 \\
\hline Sağlık ocağı & 14 & 8,0 \\
\hline Hemşirelik dışında başka bir meslek & 5 & 2,9 \\
\hline Diğer & 3 & 1,7 \\
\hline \multicolumn{3}{|c|}{ Mezuniyet Sonrası Hemşirelik Yapmak İsteme Durumu } \\
\hline İstiyorum & 141 & 80,6 \\
\hline İstemiyorum & 34 & 19,4 \\
\hline \multicolumn{3}{|l|}{ Meslekle İlgili Bilgi Alma Durumu } \\
\hline Bilgim var & 158 & 90,3 \\
\hline Bilgim yok & 13 & 7,4 \\
\hline Fikrim yok & 4 & 2,3 \\
\hline
\end{tabular}

Öğrencilerin hemşirelikte meslek seçimi ölçeği puan ortalaması $54,29 \pm 14.50$ olarak belirlenmiştir. Mesleki Uygunluk alt ölçeğinden 57,34 \pm 19,69 puan, yaşamsal faktörler alt ölçeğinden ise 48,22 $\pm 14,50$ puan aldığı saptanmıştır. Hemşirelik mesleğini seçen kız öğrencilerin puan ortalamasının 55,05 \pm 14,55, erkek öğrencilerin puan ortalaması 47,69 $\pm 12,55$ olduğu görülmektedir. Yapılan istatistiksel değerlendirme sonucunda cinsiyete göre puan ortalamaları arasında anlamlı fark olduğu belirlenmiştir ( $P=0,037)$. Bölüme isteyerek gelen öğrencilerin puan ortalaması $(60,99 \pm 11,91)$ kısmen isteyerek $(52,09 \pm 14,76)$ ve istemeyerek gelen $(45,85 \pm 12,75)$ öğrencilere göre daha yüksek olduğu ve aralarındaki farkın istatistiksel olarak önemli olduğu saptanmıştır $(P=0,00)$ (Tablo 2 ).

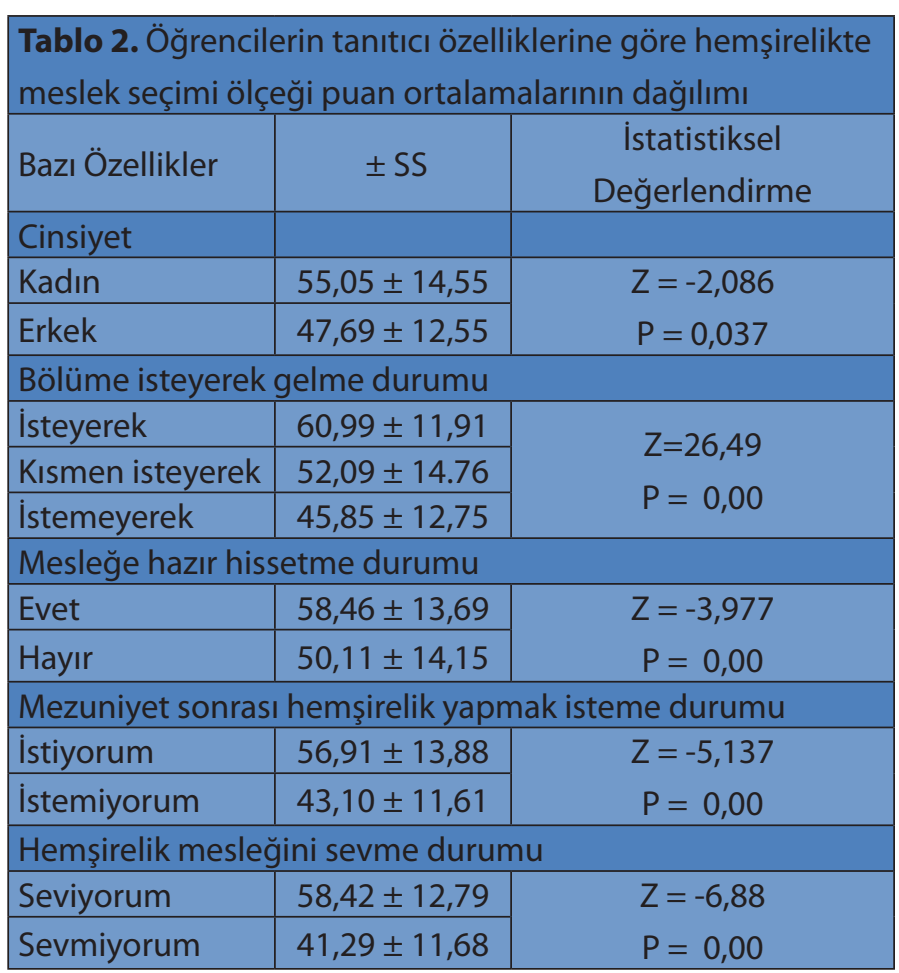

Hemşirelik mesleğine kendini hazır hissettiğini ifade eden öğrencilerin puan ortalaması $58,46 \pm 13,69$, mesleğine kendini hazır hissetmediğini ifade eden öğrencilerin puan ortalamasının $50,11 \pm 14,15$ olduğu görülmektedir. Yapılan istatistiksel değerlendirme sonucunda mesleğe kendini hazır hissetme durumuna göre puan ortalamaları arasındaki farkın anlamlı olduğu belirlenmiştir $(P=0,00)$. Mezuniyet sonrası hemşirelik yapmak isteyen öğrencilerin puan ortalamasının $(56,91 \pm 13,88)$ hemşirelik yapmak istemeyen öğrencilere $(43,10 \pm 11,61)$ göre daha yüksek olduğu görülmektedir. İstatistiksel değerlendirme sonucunda gruplar arasında fark anlamlı bulunmuştur ( $P=$ $0,00)$. Hemşirelik mesleğini sevdiğini ifade edenlerin $(58,42 \pm$ $12,79)$ sevmeyenlere $(41,29 \pm 11,68)$ göre puan ortalamasının daha yüksek olduğu ve bu farkın istatistiksel olarak anlamlı olduğu belirlenmiştir $(P=0,00)$ (Tablo2).

Öğrencilerin hemşireliktemeslekseçimiölçeğineilişkinifadelerin dağılımı incelendiğinde, öğrencilerin meslek seçiminde en önemli etken olarak ifade ettikleri \%100 seçeneğinin en fazla işaretlendiği iki madde incelendiğinde $\% 46,3$ oranıyla "Hemşirelikte işsiz kalınmayacağını düşünüyorum", \%3,.0 oranıyla "Her zaman insanlara yardım etmek istemişimdir"olarak belirlenmiştir. Meslek seçiminde etkili olmadığı ifade eden \%0 seçeneğinin en fazla işaretlendiği iki madde incelendiğinde ise, öğrencilerin \%46,9 oranıyla "Hemşirelik dışında yapabileceğim başka iş yok", \%43,7 oranıyla "Hemşirelikten başka seçim şansım yoktu" olarak belirlenmiştir (Tablo 3). 


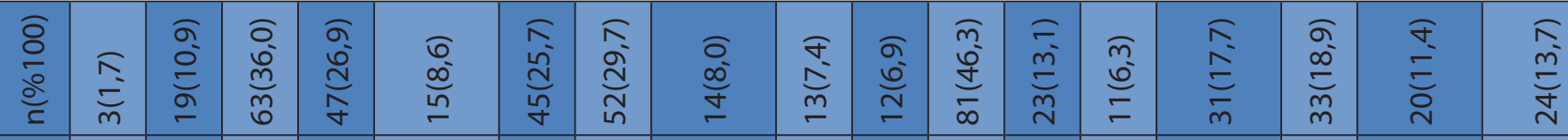

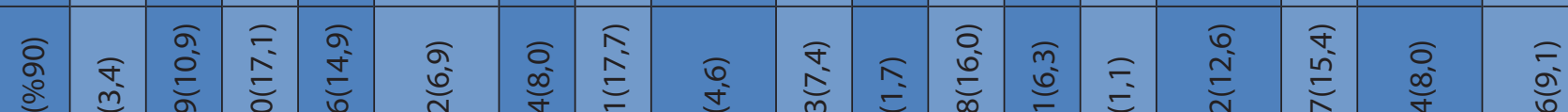
๖े

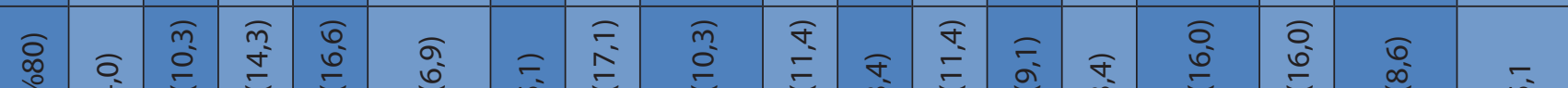

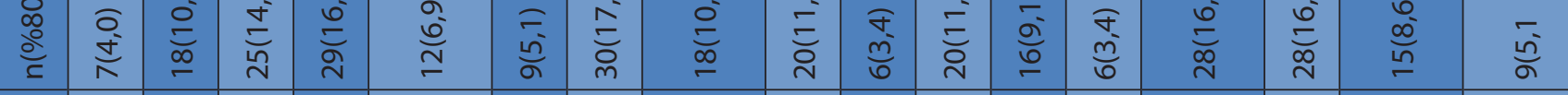

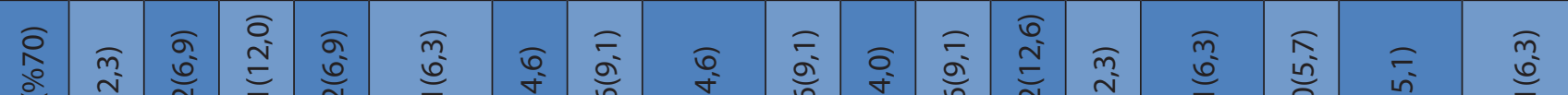

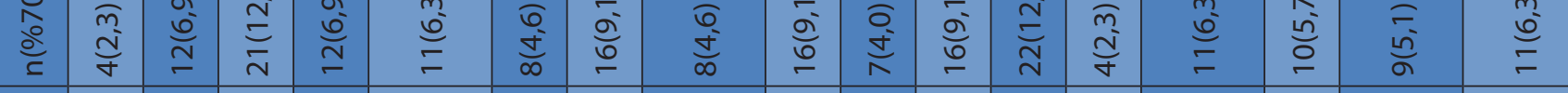

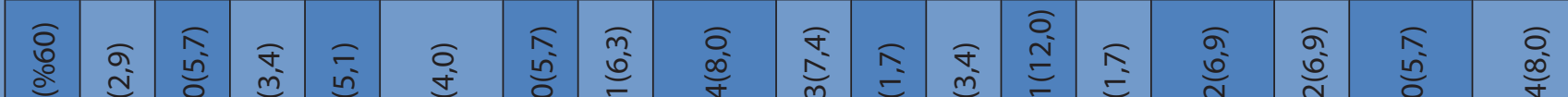

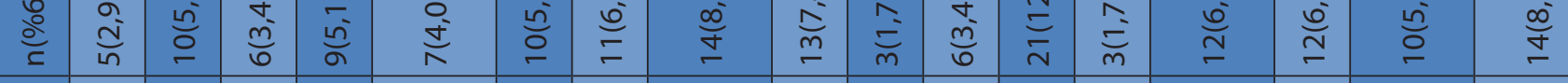

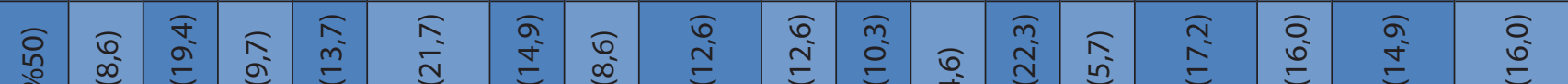

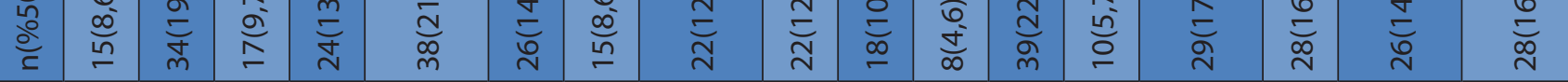

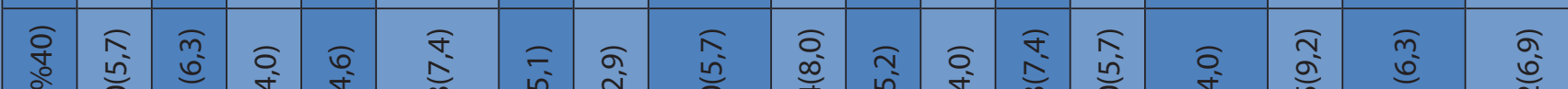

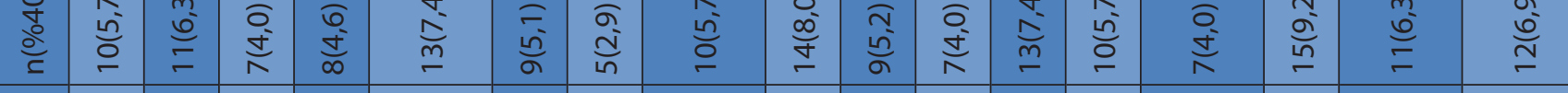

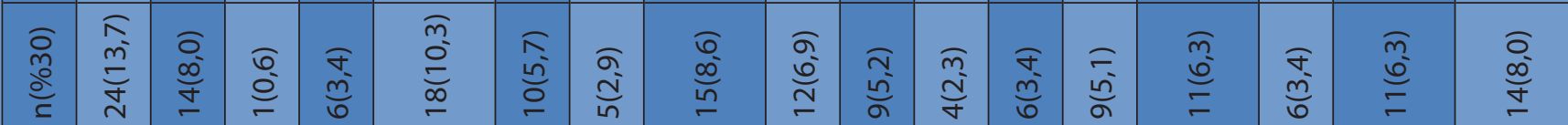

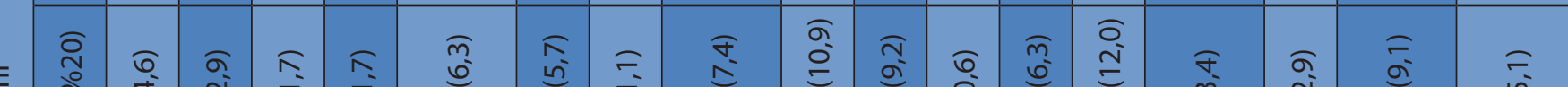

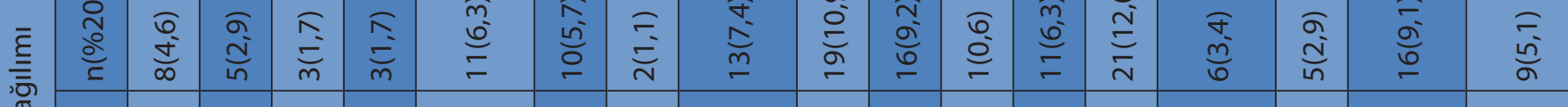

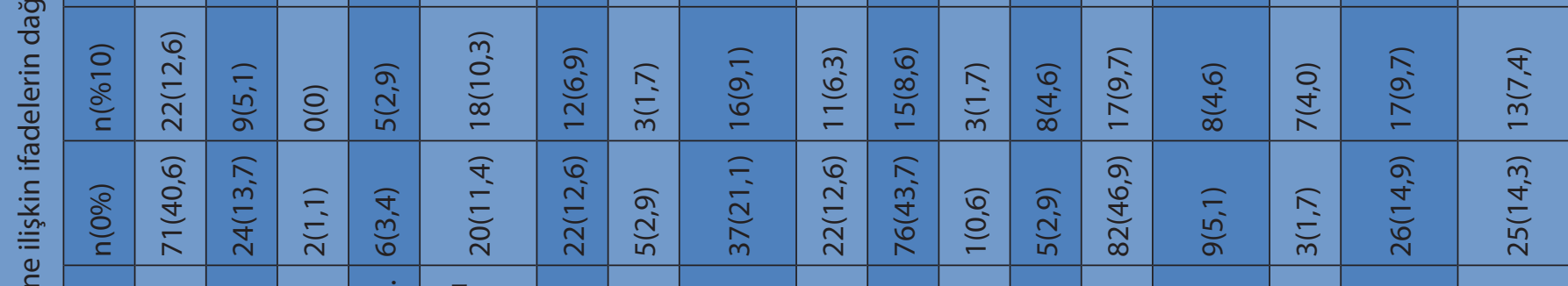

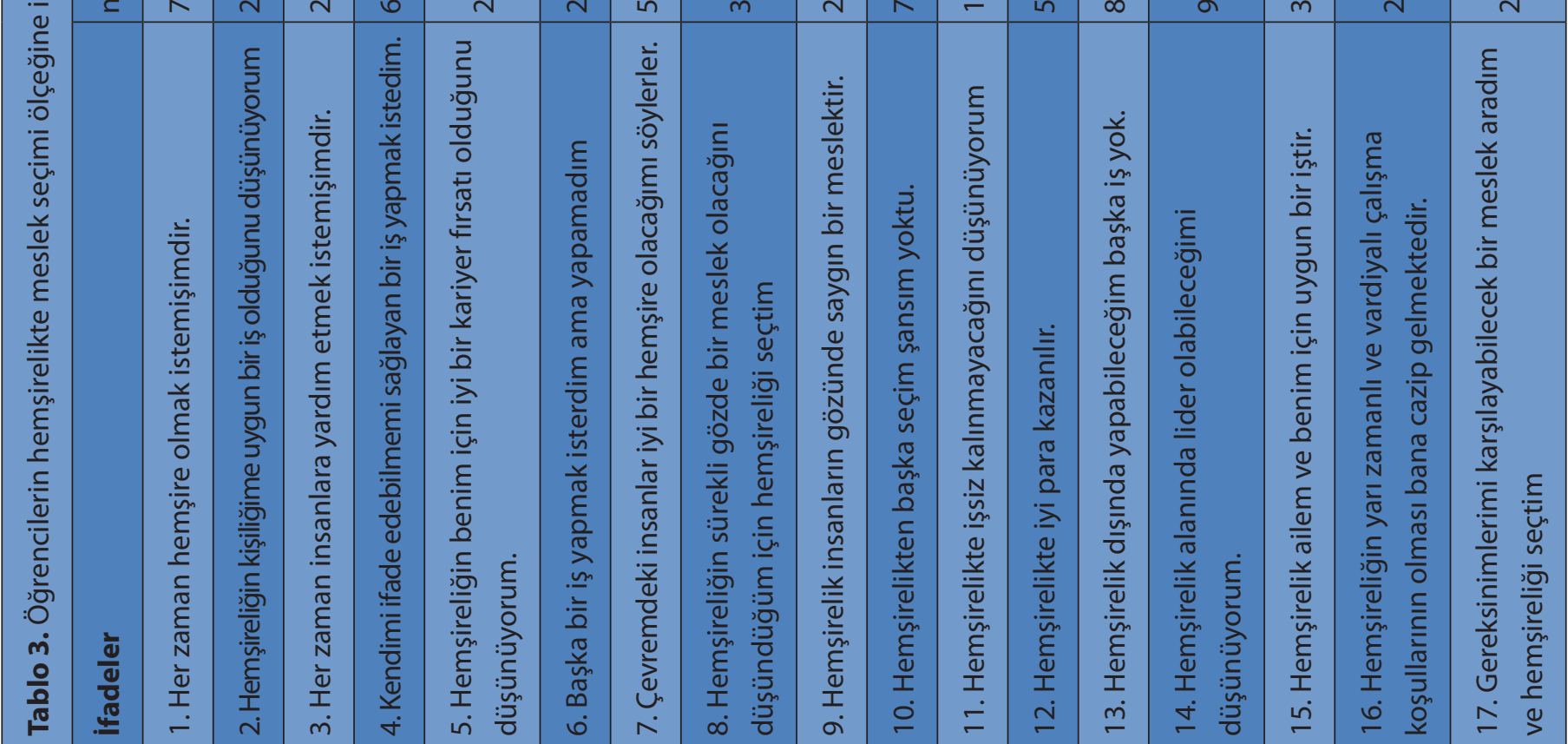




\section{Tartışma}

Meslek seçimi bireyin yaşamında çok önemlidir. Meslek seçerken bireyi etkileyen birçok faktör vardır. Çalışmamızda hemşirelik öğrencilerin tercih sıralamasına baktığımızda çoğunlukla $(\% 62,8)$ hemşirelik bölümü tercihlerinin 1-5. sırada olduğu görülmüştür. Aynı zamanda öğrencilerin yarıya yakını $(\% 40,6)$ hemşireliği kendi isteği ile seçerek geldiği, yarıya yakının (\%49.7) mesleğe kendini hazır hissettiği, büyük çoğunluğunun $(\% 76,0)$, hemşirelik mesleğini sevdiği ve tamamına yakınının ise $(\% 90,3)$ hemşirelik mesleği ile ilgili bilgisinin olduğunu belirtmiştir (Tablo1). Yapılan çalışmalarda araştırma sonuçlarımızla benzerdir [1,3,18]. Bu bulgulara göre, öğrencilerin genel olarak seçimlerini kendi istekleri doğrultusunda yaptıklarını, mesleği isteyerek ve severek tercih ettiklerini göstermektedir.

Araştırmada kız öğrencilerin $(\% 89,7)$ oranı erkek öğrencilere $(\% 10,3)$ göre daha fazla olduğu görülmektedir. Hemşirelik mesleğini seçen kız öğrencilerin puan ortalamasının erkek öğrencilerden yüksek olduğu görülmektedir (Tablo2). Tarihsel gelişim süreci içinde hemşirelik mesleği kadınlara özgü bir meslek olma özelliğini sürdürmüştür. Özellikle toplumumuzda, hastalara verilen bakımın ve özenin kadının doğası ile ilgili olduğu düşünüldüğü için yakın geçmişe kadar hemşirelik mesleği bir kadın mesleği olarak kabul edilmiştir. Bu da öğrencilerin tercihlerinde etkili olmaktadır. Bu bulgu diğer çalışmalarla benzerlik göstermektedir $[1,11,14,17,25]$. Çalışmamızdaki bu bulgu toplumda cinsiyetle ilgili meslek imajının devam ettiğini göstermesi açısından önemlidir. Hemşirelik mesleğinin ülkemizde değişen hemşirelik yasasına rağmen hala kadın mesleği olarak görünmesi ve erkek öğrencilerin bu durumdan etkileniyor olması bu farkın nedeni olarak düşünülebilir.

Bu çalışmada bölümü kendi isteği ile gelen öğrencilerin oranı \%40,6 olarak belirlenmiştir (Tablo1). Hemşirelik bölümüne isteyerek gelen öğrencilerin puan ortalamasının kısmen isteyerek ve istemeyerek gelen öğrencilere göre daha yüksek olduğu belirlenmiştir. (Tablo 2). Bu bulgu doğrultusunda öğrencilerin bu bölüme isteyerek geldikleri söylenebilir. Ayrıca bu bulgu bize hemşirelik öğrencilerinin giderek daha istekli öğrencilerden oluştuğunu göstermesi açısından önemlidir. Benzer şekilde yapılan çalışmalarda da öğrencilerin hemşirelik mesleğini isteyerek seçtikleri saptanmıştır $[3,9,11,23]$. Bireyin mesleğinde başarılı olabilmesi, mesleğini bilerek ve isteyerek seçmiş olması ile yakından ilişkilidir. İstemeden seçtikleri bölümde okuyan öğrencilerin mesleklerinde başarılı ve verimli olma olasılığı düşüktür [19].
Hemşirelik mesleğine kendini hazır hisseden öğrencilerin puan ortalamasının mesleğine kendini hazır hissetmeyenlerden daha yüksek olduğu görülmektedir (Tablo2). Araştırmada öğrencilerin \%80,6'sı mezuniyet sonrası hemşirelik yapmayı düşündüğünü ifade etmiştir (Tablo 1). Mezuniyet sonrası hemşirelik yapmak isteyen öğrencilerin puan ortalamasının daha yüksek olduğu bulunmuştur (Tablo2). Benzer şekilde Dinç ve arkadaşlarının [3] yaptığı çalışmada öğrencilerin \%82,8'i mezuniyet sonrası mesleği yapacağını ifade etmiştir. Araştırmaya katılan öğrencilerin hemşirelik mesleğine kendilerini hazır hissetmeleri ve mezun olduktan sonra hemşirelik yapmak istemeleri mesleğe yönelik iyi duygular taşıdıklarını, öğrencilerin bilinçli olarak mesleği tercih ettiklerini ve bu nedenle öğrencilerin ön yargılar içinde okula gelmediklerini düşündürmektedir. Özellikle hemşirelik alanında öğrencilerin bilinçli olarak mesleği tercih etmeleri, sevdiği ve istediği işi yapıyor olmaları öncelikle mesleki tatmini, aynı zamanda başarıyı, hasta memnuniyetini de beraberinde getirmesi açısından önemlidir [6].

Öğrencilerin çoğunluğu $(\% 76,0)$ hemşirelik mesleğini sevdiğini ifade etmiştir (Tablo1). Hemşirelik mesleğini sevdiğini ifade edenlerin puan ortalamasının sevmeyenlere göre daha yüksek olduğu görülmektedir. Öğrencilerin hemşirelik mesleğini sevdikleri yapılan diğer çalışmalarda da belirlenmiştir $[9,18]$. Elde edilen sonuçlara göre, son yıllarda hemşirelik mesleğini seçmede öğrencilerin tercihlerinin bilinçli ve farkındalığı yüksek bir seçim olduğu söylenebilir. Öğrencilerin \%90,3'nün meslekle ilgili bilgisi olduğu ifade etmesi de bu sonucu desteklemektedir (Tablo 1).

Araştırmada hemşirelik öğrencilerin \%46,3'ü "Hemşirelikte işsiz kalınmayacağını düşünüyorum" ifadesine katıldığını belirtmiştir. Ülkemizde yapılan bazı çalışmalarda hemşirelik öğrencilerinin mezuniyet sonrası iş bulma imkanının fazla olması nedeniyle hemşirelik bölümünü seçtikleri belirlenmiştir $[9,17,21]$. Ayrıca yurtdışında yapılan bazı çalışmalarda da iş güvencesi ve iyi bir gelir sağlaması nedeniyle hemşirelik mesleğinin tercih edildiği belirtilmektedir $[11,26,27]$. Ülkemizde hemşirelik bölümünün iş istihdamının yüksek olması hemşireliği tercih edilen meslekler olarak yükseltmiştir. Bu sonuç öğrencilerin hemşirelik mesleğini seçiminde etkili olabileceği düşünülmektedir.

Öğrenciler "her zaman insanlara yardım etmek istemişimdir" ifadesine $\% 36,0$ oranında katıldığını belirtmiştir. Aynı şekilde Erkal ve arkadaşları [21] yaptıkları çalışmada öğrencilerin $\% 26,0$ 'sı insanlara yardım sevdiği için hemşireliği tercih 
ettiğini belirtmiştir. Tunç ve arkadaşları [14] yaptığı çalışmada da hemşirelik öğrencilerinin üçte ikisinin $(\% 69,8)$ hemşireliği "hastalara yardım ve hizmet eden kişi" olarak ifade etmiştir. "İnsanlara yardımı sevme" nedeniyle öğrencilerin hemşirelik eğitimini seçme nedenleri bazı yabancı çalışmalarda da ele alınmıştır $[22,28,29]$. Öğrencilerin hemşirelik mesleğine ilişkin bu algılamaları aynı zamanda hemşirelik mesleğine yönelik toplumun algısını da yansıtmaktadır [14]. Hemşirelik bakımının odağında insan olduğu için öğrencilerin gelecekte mesleklerini uygularken başkalarına yardım ederek onların gereksinimlerini karşılama kendilerini iyi hissetmelerine yardımcı olacağından empati ve yardımseverlik meslek seçimlerinde önemli rol oynamıştır.

Hemşirelik mesleğinin tıp ve diğer sağlık meslekleriyle birlikte toplum içindeki yerinin önemi gerek halk, gerekse meslek üyeleri tarafından kabul edilmektedir. Hemşirelik mesleğini seçen insanlarda insanı sevme ve yardım etme değeri yüksektir. Nitekim A.B.D.de yapılan bir araştırmada hemşireliği seçme nedenleri arasında büyük bir çoğunlukla yardım etme isteği yer alırken çok düşük bir oranda ekonomik yeterlilik için tercih ettikleri belirlenmiştir [24].

Sonuç olarak öğrencilerin hemşirelikte meslek seçimi ölçeği puan ortalaması $54,29 \pm 14,50$ olarakbelirlenmiştir.Öğrencilerin meslek seçiminde cinsiyetin, bölümü isteyerek gelme durumunun, mesleğe hazır hissetme durumunun mezuniyet sonrası hemşirelik yapmak isteme ve hemşireliği sevme durumu gibi bazı değişkenlerin etkili olduğu belirlenmiştir. Bu bulgulara dayalı olarak meslek seçme aşamasında olan lise son sınıf öğrencilerinin tercihlerine yardımcı olmak amacıyla rehberlik hizmetleri daha dikkatli yapılması, ayrıca öğrencilerin hemşirelik mesleğini doğru tanımaları için özel gün ve haftalarda konferanslar düzenlenmesi, düzenlenecek olan konferanslarda tüm meslekler hakkında meslek üyeleri tarafından kapsamlı bilgiler verilmesi önerilebilir.

\section{Maddi Destek ve Çıkar İlişkisi}

Çalışmayı maddi olarak destekleyen kişi/kuruluş yoktur ve yazarların çıkara dayalı bir ilişkisi yoktur.

\section{Teşekkür Yazısı}

$\mathrm{Bu}$ çalışmanın anket uygulamasına katkılarından dolayı çalışmayı hemşirelik öğrencilerine teşekkür ederiz.

\section{Kaynaklar}

1. Çiftçi GE, Bülbül SF, Muluk NB, Duyan GÇ, Yılmaz, A. Sağlık Bilimleri Fakültesini Tercih Eden Öğrencilerin, Üniversite ve Meslek Tercihlerinde Etkili Olan Faktörler (Kırıkkale Üniversitesi Örneği). J Kartal TR 2011; 22: 151-160.

2. Sarıkaya T, Khorshid L. Üniversite öğrencilerinin meslek seçimini etkileyen etmenlerin incelenmesi: üniversite öğrencilerinin meslek seçimi. Türk Eğitim Bilimleri Dergisi 2009; 7: 393-423.

3. Dinç S, Kaya Ö, Şimşek Z. Harran üniversitesi sağlık yüksek okulu öğrencilerinin hemşirelik mesleği hakkındaki bilgi, düşünce ve beklentileri. Atatürk Üniversitesi Hemşirelik Yüksek Okulu Dergisi 2007; 10: 1-9.

4. Pekkaya M, Çolak N. Üniversite öğrencilerinin meslek seçimini etkileyen faktörlerin önem derecelerinin AHP İle belirlenmesi. The Journal of Academic Social Science Studies 2013; 6: 797-818.

5. Öztunç G. Hemşireliğin doğası. T.A. Aştı, A. Karadağ (Ed), Hemşirelik Esasları, Hemşirelik Bilim ve Sanatı. İstanbul, Akademi Basın ve Yayıncılık; 2013

6. Önler E, Saraçoğlu VG. Hemşirelikte meslek seçimi ölçeğinin güvenilirlik ve geçerliliği. Dokuzeylül Üniversitesi Hemşirelik Yüksekokulu Dergisi 2010; 3: 72-85.

7. Karadakovan A. Ege üniversitesi hemşirelik yüksekokulu öğrencilerinin mesleğin toplumdaki statüsü ve hemşireliğe erkek öğrenci alınmasına ilişkin görüşleri. III. Hemşirelik Eğitimi Sempozyumu Kitabı, İstanbul; 1993.s.376-383

8. Beydağ KD, Gündüz A, Özer FG. Sağlıkyüksekokulu öğrencilerinin eğitimlerine ve mesleklerine bakış açıları, meslekten beklentileri. Pamukkale Tıp Dergisi 2008; 1: 137-142.

9. Tüfekci FG, Yıldız A. Öğrencilerin hemşireliği tercih etme gerekçeleri ve gelecekleri ile ilgili görüşleri. Atatürk Üniversitesi Hemşirelik Yüksekokulu Dergisi 2009; 12: 31-37.

10. Çakırer N, Acar Ş, Cansu V, Doğdu G, Saraçoğlu N. Ufuk üniversitesi hemşirelik yüksekokulu öğrencilerinin hemşirelik mesleği hakkında bilgi, düşünce ve beklentileri. 10. Ulusal Uluslar arası Katılımlı Hemşirelik Öğrencileri Kongresi Bildiri Kitabı. Gaziantep; 2011. s 107.

11. Larsen PD, McGill SJ, Palmer SJ. Factors Influencing career decisions: perspectives of nursing students in three types of programs. Journal of Nursing Education 2003; 42: 168-173.

12. Mooney M, Michele G, Frances $\mathrm{O}$. Choosing nursing as a career: $A$ qualitative study. Nurse Education Today 2008; 28: 385-392. 
13. Pool L. Why do young people choose nursing as a career? Whitireia Nursing Journal 2006; 13: 25-33.

14. Tunç GÇ, Akansel N, Özdemir A. Hemşirelik ve sağlık memurluğu öğrencilerinin meslek seçimlerini etkileyen faktörler. Maltepe Üniversitesi Hemşirelik Bilim ve Sanatı Dergisi 2010; 3: 24-31.

15. Ünal S, Gürhan N, Saral E, Özbafi AA. Hemşirelik öğrencilerinin sosyodemografik özellikleri ve hemşirelik mesleğini seçme nedenleri. İstanbul Üniversitesi Florence Ningtingale. Hemşirelik. Dergisi 2008; 16: 179-187.

16. Yılmaz V, İmren B, Ünsal A, Demir G. Hemşirelik öğrencilerinin meslek seçimine yönelik görüşleri. 10. Ulusal Uluslar aras Katılımlı Hemşirelik Öğrencileri Kongresi Bildiri Kitabı. Gaziantep; 2011. s.104.

17. Özpancar N, Aydın N, Akansel N. Hemşirelik 1. sınıf öğrencilerinin hemşirelik mesleği ile ilgili görüşlerinin belirlenmesi. Cumhuriyet Üniversitesi. Hemşirelik Yüksekokulu Dergisi 2008; 12: 9-17.

18. Şirin A, Öztürk R, Bezci G, Çakar G, Çoban A. Hemşirelik öğrencilerinin meslek seçimi ve mesleği uygulamaya yönelik görüşleri. Dirim Tıp Gazetesi 2008; 83: 69-75.

19. Dindar İ, Şıpkın S. Trakya üniversitesi edirne sağlık hizmetleri meslek yüksekokulu öğrencilerinin sosyo-ekonomik özelliklerini, sorunları ve mesleksel beklentilerinin araştırılması, Türk Hemşireliğinde Yüksek Öğrenimin 40. Yılı Sempozyumu Kitabı, Ege Üniversitesi Basımevi. İzmir; 1995. s 49-57.

20. Andsoy II, Güngör T, Bayburtluoğlu T. Karabük üniversitesi sağlık yüksekokulu öğrencilerinin hemşireliği tercih etme nedenleri ve mesleğin geleceği ile ilgili görüşleri. Balıkesir Sağlık Bilimleri Dergisi 2012; 1: 124-130.
21. Erkal is, Yalçın AS, Sancar B. Ankara üniversitesi sağlık bilimleri fakültesi öğrencilerinin ebelik ve hemşirelik bölümlerini seçme nedenleri. Ankara Sağlık Bilimleri Dergisi 2012; 73-89.

22. Jirwe $M$, Rudman $A$. Why choose a career in nursing? Journal of Advnced Nursing 2012; 68: 1615-1623.

23. Kızğut S, Ergöl Ş. Sağlık yüksekokulu öğrencilerinin hemşireliği algılayışı hemşirelik rollerine ve hemşireliğin geleceğine bakışı. Anadolu Hemşirelik ve Sağlık Bilimleri Dergisi 2011;14: 10-15.

24. Zysberg L, Devon MB. Gender and students' vocational choices in entering the field of nursing. Nursing Outlook 2005; 53: 193- 198.

25. Natan MB, Becker F. Israelis'percieved motivation for choosing a nursing career. Nurse Education Today 2010; 30: 308-313

26. While A, Blackman C. Reflections on nursing as a career choice. Journal of Nursing Management 1998; 6: 231-237.

27. Seago JA, Spetz J, Alvarado A, Keane D. The nursing shortage: Is it really about image? Journal of Healthcare Management 2006; 51: 96-110.

28. Beck CT. The experience of choosing nursing as a career. Journal of Nursing Education 2000; 320-322.

29. Boughn S, Lentini A. Why do women choose nursing? Journal of Nursing Education 1999; 156-161. 